\title{
The Effect of Hemin and Deferoxamine on Selenium, Zinc, and Iron Levels of K562 Cells
}

\author{
Bahire Küçükkaya ${ }^{1}$, Lale Afrasyap ${ }^{2}$ \\ ${ }^{1}$ Department of Biophysics, Faculty of Medicine, Maltepe University, Istanbul, TURKEY; ${ }^{2}$ Muğla School of Health Sciences, Muğla \\ University, Muğla, TURKEY. \\ Email: tuyap@mu.edu.tr
}

Received November $8^{\text {th }}, 2010$; revised November $28^{\text {th }}, 2010$; accepted December $3^{\text {rd }}, 2010$.

\begin{abstract}
This study investigated contents of trace elements selenium, zinc and iron both in control K562 cells, human leukemia cell line, and cells treated with hemin or the iron chelator deferoxamine cells. K562 cell line was grown in RPMI medium supplemented with $10 \%$ fetal calf serum, $100 \mathrm{IU} / \mathrm{mL}$ penicillin, $100 \mu \mathrm{g} / \mathrm{mL}$ streptomycin, $25 \mu \mathrm{g} / \mathrm{mL}$ amphotericin $B$ and $2 \mathrm{mM} \mathrm{L}$-glutamine at $37^{\circ} \mathrm{C}$ in humidified air containing $5 \% \mathrm{CO}_{2} . \mathrm{K} 562$ cells were treated with hemin and deferoxamine from the first day to the fifth day. The trace element levels were measured by inductively coupled plasma optical emission spectrometry. Treatment of K562 cells with hemin resulted in an increase in the levels of selenium on fifth day compared with first day. No differences were observed in selenium levels of the control group compared with the hemin-induced group. Also there were no significant differences observed in the zinc levels of control cells compared with deferoxamine- and hemin-induced cells. Iron levels of hemin-induced cells were decreased on the fourth day compared with the third day. On the third day, iron levels of hemin-induced cells were significantly increased compared to the control group. Our observations suggest that alterations of selenium and zinc levels may play a role in hemin-induction and deferoxamine-inhibition, respectively. On the other hand, iron levels may influence both in hemin-induction and deferoxamine-inhibition of K562 human leukemia cell line.
\end{abstract}

Keywords: Hemin, Deferoxamine, DFO, K562, Selenium, Zinc, Iron, Trace Elements

\section{Introduction}

Trace elements such as selenium, zinc and iron are essential components of biological structures, but at the same time they can be toxic at concentrations beyond those necessary for their biological functions [1]. Some trace elements, especially copper, selenium, and zinc, are indeed involved in both humoral and cellular immunity [2,3]. Antibody production, neutrophil function, and natural killer cell activity decrease in trace element deficiency [4]. Selenium (Se), an essential trace element for normal function of many processes in mammalian cells, has been shown to affect the functions of several specific intracellular selenoproteins $[5,6]$. These selenoproteins include glutathione peroxidase (GPx) and thioredoxin reductase (TrxR), which have important antioxidant and detoxification functions [6,7]. A variety of seleniumcontaining compounds with diverse chemical structures are known to inhibit cell proliferation in vitro [8]. In addition, selenium appears to have a protective effect at various stages of carcinogenesis including both the early and later stages of cancer progression [7]. Zinc (Zn) is an essential trace element with important biological functions, depending on the structural and/or catalytic role played by zinc ions in a large variety of enzymes. Zinc plays a critical role in cellular integrity, protein synthesis, nucleic acid metabolism, contributing to cell growth, proliferation, differentiation and death [9]. Zinc homeostasis in eukaryotic cells is controlled on the levels of uptake, intracellular sequestration in zinc storing vesicles ('zincosomes'), nucleocytoplasmic distribution and elimination. Zinc can modulate cellular signal recognition, second messenger metabolism, protein kinase and protein phosphatase activities, and it may stimulate or inhibit activities of transcription factors, depending on the experimental systems studied [10]. Iron (Fe) is a critical nutritional element, essential for a variety of important biological processes, including cell growth and differenttiation, electron transfer reactions, oxygen transport, activation, and detoxification [11].

The K562 cell line is a human erythroleukemic cell line and is present in the pregranulosytic phase. K562 
cells were induced to erythroid differentiation with hemin and it has acquired the capability to synthesize hemoglobin $[12,13]$. Heme is a structural component of hemoglobin and it causes an increase in the expression of globin as well as enzymes of the heme biosynthetic pathway [14-16]. Hemin (the ferric chloride salt of heme) treatment also increases both the number of transferring receptor and the ferritin content $[17,18]$. Thus, heme plays a key role in the coordinated expression of several genes during the differentiation of erythroid cells [19].

Deferoxamine (DFO) is a bacterial siderophore known as an iron chelator. Iron chelation by DFO has been shown to inhibit the growth of and/or to induce apoptosis in malignant leukemia, neuroblastoma, melanoma, heaptoma, Kaposi's sarcoma, and cervical cancer cell lines [20-27]. When present in excess within the cell, iron can be toxic due to its ability to catalyze the formation of damaging radicals, which promote cellular injury and cell death [28] Also, it is well known that iron deficiency leads to different types of anemia. Cellular iron deficiency may influence haemopoietic cell growth and survival via downregulation of c-myc expression [29]. So, iron homeostasis necessitates a tight control of iron uptake, storage, export and appropriate management of intracellular iron distribution. Regulation of iron homeostasis occurs at the level of uptake and storage, but multicellular organisms have also evolved cellular iron export pathways to release iron from the cells and transport it within tissues [30]. Iron homeostasis plays a key role in the control of myeloid differentiation in both normal and pathological situations. Iron deprivation of undifferentiated myeloid cells, either through iron chelation or through blocking of iron uptake, induced transcription of several markers of the monocyte/macrophage lineage [31].

In this study, we examined the effects of hemin and deferoxamine on selenium, zinc, and iron levels of K562 cells.

\section{Materials \& Methods}

\subsection{Reagents}

Hemin, deferoxamine mesylate (DFO), RPMI 1640 and penicillin/streptomycin solutions were purchased from Sigma, (St Louis, MO, USA). Fetal calf serum (FCS) was from Harlan Sera-Lab (Leicestershire, UK).

\subsection{Cell Culture}

K562 cells obtained from ATCC (MD, USA) were grown in RPMI 1640 medium supplemented with $10 \%$ FCS, penicillin-streptomycin amphotericin B $(25 \mu \mathrm{g} / \mathrm{mL})$ ve L-glutamine $(2 \mathrm{mM})$ at $37^{\circ} \mathrm{C}$ in humidified air containing $5 \% \mathrm{CO}_{2}$.

\subsection{Cell Proliferation Assay}

Cell proliferation was determined by viable cell counting. Cells were treated with $20 \mu \mathrm{M}$ hemin and $50 \mu \mathrm{M}$ DFO (day " 0 ") and were harvested from the $1^{\text {st }}$ to the $5^{\text {th }}$ day. The viability of K562 cells in the presence of hemin, deferoxamine, and alone was greater than $95 \%$ as assessed by the trypan blue dye exclusion test [32]. Trypan blue stains dead or dying cells, whereas viable cells are able to repel the dye and do not stain. The K562 cells were incubated with trypan blue for 5 minutes and the number of dead cells was counted using a hemocytometer.

\subsection{Analytical Techniques}

Cells were collected by low speed ( $400 \mathrm{~g}$ ) centrifugation and washed twice with ice-cold phosphate-buffered saline (PBS), $\mathrm{pH}$ 7.4. The cell pellets were stored at $-70^{\circ} \mathrm{C}$. Levels of total cell selenium, zinc, and iron were determined in triplicate samples of $2.5 \times 10^{6}$ cells suspended in $1 \mathrm{~mL}$ HBS buffer (150 mM NaCL, $20 \mathrm{mM}$ Hepes). The cells were mixed with $1 \mathrm{~mL}$ acid mixture (3 N HCL, $10 \%$ trichloroacetic acid, and 3\% thioglycolic acid) and incubated for 2 hours at $37^{\circ} \mathrm{C}$, cooled, centrifuged at $3000 \mathrm{rpm}$ for 30 minutes, and mixed with $0.5 \mathrm{~mL}$ bathophenanthroline sulfonate $(0.045 \%$ in $4.5 \mathrm{~N} \mathrm{Na}$-acetate, $0.2 \%$ thioglycolic acid). The absorbances were measured by "Inductively Coupled Plasma-Optical Emission Spectrometry" (ICP-OES) (Optima 2000, PerkinElmer Life and Analytical Sciences, Inc.). The original reagents of the instrument were used in all of the trace element analysis [33]. Also, absorbances of selenium, zinc, and iron in samples were referred against a standard curve .

\section{Statistical Analysis}

Statistical analyses were made using SPSS software (version 11.5, for Windows). All data were analyzed using one-way ANOVA followed by Post-Hoc multiple comparison test. Differences were considered significant at $\mathrm{p}<0.05$. Results were expressed as mean values \pm SEM.

\section{Results}

\subsection{Comparison of the Effects of DFO and Hemin on Inhibition of Cellular Proliferation of K562 Cell Line}

A trypan blue stain viability test was performed for the K562 cells produced, and those were used to obtain cell pellets at various time periods, the following treatments; without DFO and hemin treatment as a control group, and; with treatment of various DFO and hemin concentrations as an experimental group. Figure 1 shows the effects of DFO and hemin on cellular proliferation of the 


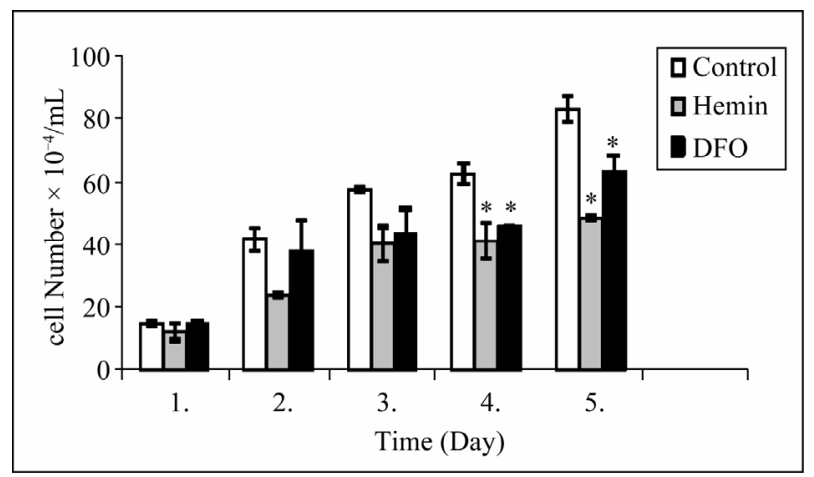

Figure 1. Daily cell counts were performed for the 5 days after no treatment (control), hemin treatment, and DFO treatment. Viable cells were counted at 1 day intervals. K562, human leukemia cell line was treated with $20 \mu \mathrm{M}$ hemin and $50 \mu \mathrm{M}$ deferoxamine. Error bars are means \pm S.E.M. for three experiments *Statistically significant difference compared to control group $(p<0.05)$.

K562 cell line at various times after subculture. Cell proliferation was suppressed within 24 hours after treatment with DFO and hemin. There was significant inhibition of cell proliferation on the $4^{\text {th }}$ and $5^{\text {th }}$ days of hemin induced and DFO induced cells, compared with control cells.

\subsection{Hemin and DFO Effects on K562 Cell Selenium Concentrations (Table 1)}

\subsubsection{Comparing Daily Results}

Selenium levels of control cells decreased significantly on the $4^{\text {th }}$ day compared with the results from the $1^{\text {st }}$ day $(46 \%)$, and $2^{\text {nd }}$ day $(43 \%),(\mathrm{p}=0.022, \mathrm{p}=0.002$ respectively). Selenium levels of hemin induced cells increased significantly $(78 \%)$ on the $5^{\text {th }}$ day compared with the $1^{\text {st }}$ day $(p=0.007)$. Selenium levels of DFO-induced cells showed no significant difference in selenium levels between different days.

\subsubsection{Comparing Group Results}

No significant differences were observed in selenium levels of the control group compared with the DFO-induced group and hemin induced group from the $1^{\text {st }}$ to the $5^{\text {th }}$ day, respectively.

\subsection{Hemin and DFO Effects on K562 Cell Zinc Concentrations (Table 2)}

\subsubsection{Comparing Daily Results}

Zinc levels of control cells increased significantly on the $1^{\text {st }}, 2^{\text {nd }}$, and $3^{\text {rd }}$ days $(102 \%, 129 \%$, and $53 \%$ respectively) compared with the $4^{\text {th }}$ day $(\mathrm{p}=0.049, \mathrm{p}=0.048, \mathrm{p}=$ 0.042 respectively). In contrast, zinc levels were significantly decreased (37\%) on the $5^{\text {th }}$ day compared with the results of the $4^{\text {th }}(p=0.045)$. Zinc levels of hemin-induced cells showed no significant difference in zinc levels between different days. Zinc levels of DFO-induced cells
Table 1. Selenium levels in control, hemin- and DFO-treated K562 cells.

\begin{tabular}{cccc}
\hline \multicolumn{4}{c}{ Selenium concentrations $\left(\mu \mathrm{M} / 1 \times 10^{9}\right.$ cells $)$} \\
\hline $\begin{array}{c}\text { Group } \\
\text { Days }\end{array}$ & $\begin{array}{c}\text { Control } \\
\mathrm{n}=3\end{array}$ & $\begin{array}{c}\text { Hemin } \\
\mathrm{n}=3\end{array}$ & $\begin{array}{c}\text { Deferoxamine } \\
\mathrm{n}=3\end{array}$ \\
\hline 1. Day & $179.73 \pm 36.03^{\mathrm{a}}$ & $107.78 \pm 16.29^{\mathrm{b}}$ & $126.50 \pm 35.34^{\mathrm{c}}$ \\
2. Day & $170.40 \pm 26.88^{\mathrm{d}}$ & $138.13 \pm 23.98^{\mathrm{e}}$ & $80.72 \pm 5.97^{\mathrm{f}}$ \\
3. Day & $97.89 \pm 30.80^{\mathrm{g}}$ & $181.06 \pm 37.04^{\mathrm{h}}$ & $78.00 \pm 9.00^{\mathrm{i}}$ \\
4. Day & $97.65 \pm 25.96^{\mathrm{j}}$ & $154.13 \pm 25.87^{\mathrm{k}}$ & $144.00 \pm 30.11^{\mathrm{l}}$ \\
5. Day & $100.64 \pm 21.28^{\mathrm{m}}$ & $191.20 \pm 22.03^{\mathrm{n}}$ & $103.97 \pm 35.28^{\mathrm{p}}$ \\
\hline
\end{tabular}

Results represent the mean \pm S.E.M. of three experiments. $a-j ; p=0.022$, d-j; $\mathrm{p}=0.002, \mathrm{~b}-\mathrm{n} ; \mathrm{p}=0.007$.

Table 2. Zinc levels in control, hemin- and DFO-treated $\mathrm{K562}$ cells.

\begin{tabular}{cccc}
\hline \multicolumn{4}{c}{ Zinc concentrations $\left(\mu \mathrm{M} / 1 \times 10^{9}\right.$ cells $)$} \\
\hline $\begin{array}{c}\text { Group } \\
\text { Days }\end{array}$ & $\begin{array}{c}\text { Control } \\
\mathrm{n}=3\end{array}$ & $\begin{array}{c}\text { Hemin } \\
\mathrm{n}=3\end{array}$ & $\begin{array}{c}\text { Deferoxamine } \\
\mathrm{n}=3\end{array}$ \\
\hline 1. Day & $210.66 \pm 19.93^{\mathrm{a}}$ & $206.00 \pm 42.33 .27^{\mathrm{b}}$ & $219.00 \pm 18.52^{\mathrm{c}}$ \\
2. Day & $186.66 \pm 14.93^{\mathrm{d}}$ & $343.33 \pm 162.70^{\mathrm{e}}$ & $242.00 \pm 25.87^{\mathrm{f}}$ \\
3. Day & $279.20 \pm 62.05^{\mathrm{g}}$ & $353.33 \pm 106.05^{\mathrm{h}}$ & $380.33 \pm 40.48^{\mathrm{i}}$ \\
4. Day & $426.40 \pm 58.56^{\mathrm{j}}$ & $241.00 \pm 32.34^{\mathrm{k}}$ & $245.33 \pm 22.52^{1}$ \\
5. Day & $268.00 \pm 30.24^{\mathrm{m}}$ & $372.33 \pm 66.55^{\mathrm{n}}$ & $195.00 \pm 7.77^{\mathrm{p}}$ \\
\hline
\end{tabular}

Results represent the mean \pm S.E.M. of three experiments. $a-j ; p=0.049, d-j$; $\mathrm{p}=0.048, \mathrm{~g}-\mathrm{j} ; \mathrm{p}=0.042, \mathrm{j}-\mathrm{m} ; \mathrm{p}=0.045, \mathrm{c}-\mathrm{i} ; \mathrm{p}=0.035, \mathrm{i}-\mathrm{p} ; \mathrm{p}=0.05$.

increased significantly (74\%) on day 3 , compared with day $1(\mathrm{p}=0.035)$, on the other hand the levels decreased significantly on day $5(49 \%)$, compared with day $3(\mathrm{p}=$ $0.030)$.

\subsubsection{Comparing Group Results}

No significant differences were observed in the zinc levels of the control group compared with DFO- and hemininduced groups from the $1^{\text {st }}$ to the $5^{\text {th }}$ day.

\subsection{Hemin and DFO Effects on K562 Cell Iron Concentrations (Table 3)}

\subsubsection{Comparing Daily Results}

Iron levels of control cells decreased significantly $(41 \%$, $70 \%$, and $28 \%$ respectively) on days 2,3 , and 5 compared with day $1(\mathrm{p}=0.027, \mathrm{p}=0.003, \mathrm{p}=0.033$ respectively). In contrast, iron levels increased significantly $(142 \%)$ on day 5 , compared with day $3(p=0.004)$. Iron levels of hemin-induced cells decreased significantly $30 \%$ on day 4 , compared with day $3(\mathrm{p}=0.016)$. Iron levels of DFO-induced cells decreased significantly $(22 \%)$ on day 3 , compared with day $2(\mathrm{p}=0.002)$. 
Table 3. Iron levels in control, hemin- and DFO-treated $\mathrm{K562}$ cells.

\begin{tabular}{cccc}
\hline \multicolumn{4}{c}{ Iron Concentrations $\left(\mu \mathrm{M} / 1 \times 10^{9}\right.$ cells $)$} \\
\hline Group & $\begin{array}{c}\text { Control } \\
\mathrm{n}=3\end{array}$ & $\begin{array}{c}\text { Hemin } \\
\mathrm{n}=3\end{array}$ & $\begin{array}{c}\text { Deferoxamine } \\
\mathrm{n}=3\end{array}$ \\
\hline 1. Day & $644.33 \pm 45.37^{\mathrm{a}}$ & $398.33 \pm 53.7^{\mathrm{b}}$ & $559.66 \pm 154.97^{\mathrm{c}}$ \\
2. Day & $381.66 \pm 2.02^{\mathrm{d}}$ & $399.33 \pm 50.1^{\mathrm{e}}$ & $426.33 \pm 14.05^{\mathrm{f}}$ \\
3. Day & $192.33 \pm 47.08^{\mathrm{g}}$ & $478.33 \pm 23.31^{\mathrm{h}}$ & $330.66 \pm 10.68^{\mathrm{i}}$ \\
4. Day & $575.33 \pm 138.85^{\mathrm{j}}$ & $332.00 \pm 33.05^{\mathrm{k}}$ & $437.66 \pm 56.52^{1}$ \\
5. Day & $464.33 \pm 33.39^{\mathrm{m}}$ & $441.66 \pm 59.42^{\mathrm{n}}$ & $438.33 \pm 47.83^{\mathrm{p}}$ \\
\hline
\end{tabular}

Results represent the mean \pm S.E.M. of three experiments. a-d; $p=0.027$, $\mathrm{a}-\mathrm{g} ; \mathrm{p}=0.003, \mathrm{a}-\mathrm{m} ; \mathrm{p}=0.033, \mathrm{~g}-\mathrm{m} ; \mathrm{p}=0.004, \mathrm{~h}-\mathrm{k} ; \mathrm{p}=0.016, \mathrm{f}-\mathrm{I} ; \mathrm{p}=0.002$, $\mathrm{g}-\mathrm{h} ; \mathrm{p}=0.002, \mathrm{~h}-\mathrm{I} ; \mathrm{p}=0.045$.

\subsubsection{Comparing Group Results}

On the $3^{\text {rd }}$ day, iron levels of hemin-induced cells $(60 \%)$ were significantly increased compared to the control $(\mathrm{p}=$ 0.002 ). Whereas it was observed that the levels of DFOinduced cells were significantly decreased $(31 \%)$ as compared with day 3 of hemin-induced cells $(p=0.045)$.

\section{Discussion}

A number of essential trace elements play a major role in various metabolic pathways. Selenium, manganese, copper, zinc, and iron are essential trace elements that have been studied in many diseases, cell proliferations, and differentiations. Hematopoiesis in vertebrates, which is a complicated multistep process, is a paradigm for the development of diverse specialized cell types from multipotential stem-cells. These processes are associated with a series of molecular events. The molecular events that govern these processes are only partially understood [34]. The function of erythrocyte is oxygen delivery. Erythropoiesis is a complex multistep process. Obtaining synchronized cells from long-term cultured proerythroblast cells is very difficult which led us to use K562 cells, which were suitable for this study. The K562 cell line has been used as a model of common progenitor of erythroblasts and megakaryocytes and can be differentiated into erythroid and megakaryocytic lineages by hemin (ferriprotoporphyrin IX) and phorbol myristate acetate (PMA) respectively [34].

In this study, K562 cells were treated with hemin as an erythroid differentiation inducer and DFO as an iron chelator. Hemin caused accumulation of hemoglobin in K562 cells and diminished growth potential of the cells [35-37]. On the other hand, DFO has also been shown to have antiproliferative effects on a number of cell lines in vitro, including various carcinomas, hepatoma, leukemia, and neuroblastoma cells [21-26]. We have also demon- strated that DFO and hemin treatment caused the inhibition of K562 cell proliferation.

The levels of trace metals such as selenium, zinc, and iron in DFO- and hemin-induced K562 cells have not been previously been assessed. We observed differences between iron, selenium, and zinc levels of DFO-induced and control cells on each day of the study. No differences were found in selenium levels of DFO-induced K562 cells. However, there were differences between the selenium levels of hemin-induced and control cells. The result can be interpreted that the proliferation of control and hemin-induced cells might be regulated by alternative selenium levels. However, it is still unknown the mechanism underlying the role of selenium in cellular proliferation and survival. On the other hand it is a necessary trace element for the cell culture [38].

There were changes in intracellular zinc levels of DFO-induced and control cells, but hemin-induced cells. Maclean et al. previously showed that the addition of iron chelators to murine thymocytes decreased intracellular zinc levels within 1 hour of incubation [39]. No chelator is entirely specific for a given metal, and both DFO and deferiprone chelate metals than iron (III) [39]. Also it was suggested that high zinc levels in C6 cells cause programmed cell death [40].

We observed daily differences in iron levels of heminand DFO-treated cells and control cells on each day of the study. Iron is a major factor controlling hematopoiesis [30]. DFO-induced iron deprivation blocks erythroid lineage differentiation of $\mathrm{K} 562$ cells in a standard in vitro system [41]. In contrast, treatment of K562 cells with hemin induces erythroid differentiation [41].

It is evident from the results of the present study that alterations of selenium and zinc levels may play a role in hemin-induction and DFO-inhibition of K562 cells, respectively. On the other hand, different iron levels may be effective in both hemin-induction and DFO-inhibition of the cells. Better understanding of the effects of hemin and deferoxamine on trace elements of K562 human leukemia cell line, further studies are required on this subject.

\section{Acknowledgements}

We thank to Assist. Prof. Dr. U. O. Turkcu who helped in laboratory analysis of the study.

\section{REFERENCES}

[1] C. G. Fraga, "Relevance, Essentiality and Toxicity of Trace Elements in Human Health," Molecular Aspects of Medicine, Vol. 26, No. 4-5, August 2005, pp. 235-244. doi:10.1016/j.mam.2005.07.013

[2] M. Allgöwer, G. A. Schoenenberger and B. G. Sparkes, "Burning the Largest Immune Organ," Burns, Vol. 21, 
Suppl. 1, 1995, pp. S7-47. doi:10.1016/0305-4179(95)90028-4

[3] H. H. Sandstead, "Understanding Zinc: Recent Observation and Interpretations," Journal of Laboratory and Clinical Medicine, Vol. 124, No. 3, September 1994, pp. 322-327.

[4] M. M. Berger, F. Spertini, A. Shenkin, C. Wardle, L. Wiesner, C. Schindler and R. L. Chiolero, "Trace Element Supplementation Modulates Pulmonary Infection Rates after Major Burns: A Double-Blind, Placebo-Controlled Trial," The American Journal of Clinical Nutrition, Vol. 68, No. 2, August 1998, pp. 365-371.

[5] K. S. Abul-Hassan, B. E. Lehnert, L. Guant and R. Walmsley, "Abnormal DNA Repair in Selenium-Treated Human Cells," Mutation Research, Vol. 565, No. 1, December 2004, pp. 45-51.

[6] C. B. Allan, G. M. Lacourciere and T. C. Stadtman, "Responsiveness of Selenoproteins to Dietary Selenium," Annual Review of Nutrition, Vol. 19, 1999, pp. 1-16. doi:10.1146/annurev.nutr.19.1.1

[7] H. Zeng and G. F. Combs, "Selenium as an Anticancer Nutrient: Roles in Cell Proliferation and Tumor Cell Invasion," The Journal of Nutritional Biochemistry, Vol. 19, No. 1, January 2008, pp. 1-7.

doi:10.1016/j.jnutbio.2007.02.005

[8] C. Ip, H. J. Thompson and H. E. Ganther, "Selenium Modulation of Cell Proliferation and Cell Cycle Biomarkers in Normal and Premalignant Cells of the Rat Mammary Gland," Cancer Epidemiology, Biomarkers Prevention, Vol. 9, No. 1, January 2000, pp. 49-54.

[9] B. L. Vallee and K. H. Falchuk, "The Biochemical Basis of Zinc Physiology," Physiological Reviews, Vol. 73, No. 1, January 1993, pp. 79-118.

[10] D. Beyersmann and H. Haase, "Functions of Zinc in Signaling, Proliferation and Differentiation of Mammalian Cells," Biometals, Vol. 14. No. 3-4, September 2001, pp. 331-341. doi:10.1023/A:1012905406548

[11] L. Brard, C. O. Granai and N. Swamy, "Iron Chelators Deferoxamine and Diethylenetriamine Pentaacetic Acid Induce Apoptosis in Ovarian Carcinoma," Gynecologic Oncology, Vol. 100, No. 1, January 2006, pp. 116-127. doi:10.1016/j.ygyno.2005.07.129

[12] C. B. Lozzio and B. B. Lozzio, "Human Chronic Myelogenous Leukemia Cell Line with Positive Philadelphia Chromosome," Blood, Vol. 45, March 1975, pp. 321-334.

[13] T. R. Rutherford, J. B. Clegg and D. J. Weatherall, "K562 Human Leukemia Cells Synthetize Embryonic Hemoglobin in Response to Hemin," Nature, Vol. 280, No. 5718, July 1979, pp. 164-165. doi:10.1038/280164a0

[14] P. Charnay and T. Maniatis, "Transcriptional Regulation of Globin Gene Expression in the Human Erythroid Cell Line K562," Science, Vol. 220, January 1983, pp. 1281-1283. doi:10.1126/science. 6574602

[15] S. Sassa and T. Nagai, "The Role of Heme in Gene Expression," International Journal of Hematology, Vol. 63, No. 3, April 1996, pp. 167-178. doi:10.1016/0925-5710(96)00449-5

[16] Y. Fukuda, H. Fujita, S. Taketani and S. Sassa, "Dimethyl Sulphoxide and Haemin Induce Ferrochelatase mRNA by Different Mechanisms in Murine Erythroleukaemia Cells," British Journal of Haematology, Vol. 83, No. 3, March 1993, pp. 670-675. doi:10.1111/j.1365-2141.1993.tb03207.x

[17] A. Battistini, G. Marziali, R. Albertini, D. Bulgarini, E. M. Coccia, G. Fiorucci, G. Romeo, R. Orsatti, R. Testa, G. B. Rossi and C. Peschle, "Positive Modulation of Hemoglobin, Heme, and Transferring Receptor Synthesis by Murine Interferonalpha and Differentiating Friend Cells. Pivotal Role of Heme Synthesis," Journal of Biological Chemistry, Vol. 266, No. 1, January 1991, pp. 528-535.

[18] E. M. Coccia, V. Profita, G. Fiorucci, G. Romeo, E. Affabris, U. Testa, M. W. Hentze and A. Battistini, "Modulation of Ferritin H-Chain Expression in Friend Erythroleukemia Cells: Transcriptional and Translational Regulation by Hemin," Molecular and Cellular Biology, Cell Biology, Vol. 12, No. 7, July 2004, pp. 3015-3022.

[19] T. Tahara, J. Sun, K. Nakanishi, M. Yamamoto, H. Mori, T. Saito, H. Fujita, K. Igarashi and S. Taketan, "Heme Positively Regulates the Expression of Beta-Globin at the Locus Control Region via the Transcriptional Factor Bach1 in Erythroid Cells," Journal of Biological Chemistry, Vol. 279, No. 7, February 2004, pp. 5480-5487.

[20] R. U. Haq, J. P. Werely and C. R. Chitambar, "Induction of Apoptosis by Iron Deprivation in Human Leukemic CCRF-CEM Cells," Experimental Hematology, Vol. 23, No. 5, May 1995, pp. 428-432.

[21] D. L. Becton and P. Bryles, "Deferoxamine Inhibition of Human Neuroblastoma Viability and Proliferation," Cancer Research, Vol. 48, No. 24, December 1988, pp. 7189-7192.

[22] C. Brodie, G. Siriwardana, J. Lucas, R. Schleicher, N. Terada, A. Szepesi, E. Gelfand and P. Seligman, "Neuroblastoma Sensitivity to Growth Inhibition by Desferrioxamine. Evidence for Block in G1 Phase of the Cell Cycle," Cancer Research, Vol. 53, No. 17, September 1993, pp. 3968-3975.

[23] D. Richardson, P. Ponka and E. Baker, "The Effect of the Iron(III) Chelator, Desferrioxamine, on Iron and Transferring Uptake by the Human Malignant Melanoma Cell,' Cancer Research, Vol. 54, No. 3, February 1994, pp. 685- 689.

[24] H. W. Hann, M. W. Stahlhut and C. L. Hann, "Effect of Iron and Desferoxamine on Cell Growth and in vitro Ferritin Synthesis in Human Hepatoma Cell Lines," Hepatology, Vol. 11, No. 4, April 1990, pp. 566-569. doi:10.1002/hep.1840110407

[25] T. Simonart, C. Degraef, G. Andrei, R. Mosselmans, P. Hermans, J. P. Van Vooren, J. C. Noel, J. R. Boelaert, R. Snoeck and M. Heenen, "Iron Chelators Inhibit the Growth and Induce the Apoptosis of Kaposi's Sarcoma Cells and of Their Putative Endothelial Precursors," Journal of Investigative Dermatology, Vol. 115, No. 5, November 2000, pp. 893-900. doi:10.1046/j.1523-1747.2000.00119.x 
[26] T. Simonart, J. R. Boelaert, R. Mosselmans, G. Andre, J. C. Noel, E. De Clercq and R. Snoeck, "Antiproliferative and Apoptotic Effects of Iron Chelators on Human Cercival Carcinoma Cells," Gynecologic Oncology, Vol. 85, No. 1, April 2002, pp. 95-102. doi:10.1006/gyno.2001.6570

[27] H. J. Lee, J. Lee, S. K. Lee and E. C. Kim, "Differential Regulation of Iron Chelator-Induced IL-8 Synthesis via MAP Kinase and NF- $\kappa \mathrm{B}$ in Immortalized and Malignant Oral Keratinocytes," BMC Cancer, Vol. 13, No. 7, September 2007, p. 176.

[28] M. A. Philippe, R. G. Ruddell and G. A. Ramm, "Role of Iron in Hepatic Fibrosis: Piece in the Puzzle," World Journal of Gastroenterology, Vol. 13, No. 35, September 2007, pp. 4746-4754.

[29] D. Kyriakou, A. G. Eliopoulos, A. Papadakis, M. Alexandrakis and G. D. Eliopoulos, "Decreased Expression of C-myc Oncoprotein by Peripheral Blood Mononuclear Cells in Thalassaemia Patients Receiving Desferrioxamine," European Journal of Haematology, Vol. 60, No. 1, January 1998, pp. 21-27.

[30] L. Cianetti, P. Segnalini, A. Calzolari, O. Morsilli, F. Felicetti, C. Ramoni, M. Gabbianelli, U. Testa and N. M. Sposi, "Expression of Alternative Transcripts of Ferroporin-1 during Human Erythroid Differentiation," Haematologica, Vol. 90, No. 12, December 2005, pp. 1595- 1606.

[31] C. Callens, S. Coulon, J. Naudin, I. Radford-Weiss, E. Raffoux, P. H. Wang, S. Agarwal, H. Tamouza, E. Paubelle, V. Asnafi, J. A. Ribeil, P. Dessen, D. Canioni, O. Chandesris, M. T. Rubio, C. Beaumont, M. Benhamou, H. Dombret, E. Macintyre, R. C. Monteiro, I. C. Moura and O. Hermine, "Targeting Iron Homeostasis Induces Cellular Differentiation and Synergizes with Differentiating Agents in Acute Myeloid Leukemia," The Journal of Experimental Medicine, Vol. 207, No. 4, April 2010, pp. 731-750. doi:10.1084/jem.20091488

[32] I. U. Pardoe, K. K. Grewal, M. P. Baldeh, J. Hamid and A. T. Burness, "Persistent Infection of K562 Cells by Encephalomyocarditis Virus," The Journal of Virology, Vol. 64, No. 12, December 1990, pp. 6040-6044.

[33] O. Kahklon, Y. Gruenbaum and Z. I. Cabantchik, "Repression of Ferritin Expression Increases the Labile Iron Pool, Oxidative Stress, and Short-Term Growth of $\mathrm{Hu}-$ man Erythroleukemia Cells," Blood, Vol. 97, No. 9, May 2001, pp. 2863-2871. doi:10.1182/blood.V97.9.2863

[34] X. F. Huo, J. Yu, H. Peng, Z. W. Du, X. L. Liu, Y. N. Ma, X. Zhang, Y. Zhang, H. L. Zhao and J. W. Zhang, "Differential Expression Changes in K562 Cells during the Hemin-Induced Erythroid Differentiation and the Phorbol Myristate Acetate (PMA)-Induced Megakaryocytic Differentiation," Molecular and Cellular Biochemistry, Vol. 292, No. 1-2, November 2006, pp. 55-167.

[35] K. Iwasaki, E. L. Mackenzie, K. Hailemariam, K. Sakamoto and Y. Tsuji, "Hemin-Mediated Regulation of an Antioxidant-Responsive Element of the Human Ferritin H Gene and Role of Ref-1 during Rrythroid Differentiation of K562 Cells," Molecular and Cellular Biology, Vol. 26, No. 7, April 2006, pp. 2845-2856. doi:10.1128/MCB.26.7.2845-2856.2006

[36] B. Küçükkaya, G. Öztürk and L. Yalçıntepe, "Nitric Oxide Levels during Erythroid Differentiation in K562 Cell Line," Indian Journal of Biochemistry and Biophysics, Vol. 43, No. 4, August 2006, pp. 251-253.

[37] B. Kucukkaya, D. O. Arslan and B. Kan, "Role of G Proteins and ERK Activation in Hemin-Induced Erythroid Differentiation of K562 Cells," Life Sciences, Vol. 78, No. 11, February 2006, pp. 1217-1224. doi:10.1016/j.lfs.2005.06.041

[38] Y. Saito, Y. Yoshido, T. Akazawa, K. Takahashi and E. Niki, "Cell Death Caused by Selenium Deficiency and Protective Effect of Antioxidants," Journal of Biological Chemistry, Vol. 278, No. 41, October 2003, pp. 3942839434. doi:10.1074/jbc.M305542200

[39] K. H. Maclean, J. L. Cleveland and J. B. Porter, "Cellular Zinc Content is a Major Determinant of Iron Chelator-Induced Apoptosis of Thymocytes," Blood, Vol. 98, No. 13, December 2001, pp. 3831-3839.

[40] W. Watjen, H. Haase, M. Biagioli and D. Beyersmann, "Induction of Apoptosis in Mammalian Cells by Cadmium and Zinc," Environmental Health Perspectives, Vol. 5, suppl. 5, October 2002, pp. 865-867.

[41] O. Alcantara and D. H. Boldt, "Iron Deprivation Blocks Multilineage Haematopoietic Differentiation by Inhibiting Induction of p21 (WAF1/CIP1)," British Journal of Haematology, Vol. 137, No. 3, May 2007, pp. 252-261. doi:10.1111/j.1365-2141.2007.06549.x 